University of Nebraska - Lincoln

DigitalCommons@University of Nebraska - Lincoln

Faculty Papers and Publications in Animal

Science

Animal Science Department

1991

\title{
Feeding Value of Grain Sorghum for the Lactating Sow
}

\author{
G. F. Louis \\ University of Nebraska-Lincoln
}

A. J. Lewis

University of Nebraska-Lincoln, alewis2@unl.edu

E. R. Peo, Jr.

University of Nebraska-Lincoln

Follow this and additional works at: https://digitalcommons.unl.edu/animalscifacpub

Part of the Animal Sciences Commons

Louis, G. F.; Lewis, A. J.; and Peo, Jr., E. R., "Feeding Value of Grain Sorghum for the Lactating Sow" (1991). Faculty Papers and Publications in Animal Science. 691.

https://digitalcommons.unl.edu/animalscifacpub/691

This Article is brought to you for free and open access by the Animal Science Department at DigitalCommons@University of Nebraska - Lincoln. It has been accepted for inclusion in Faculty Papers and Publications in Animal Science by an authorized administrator of DigitalCommons@University of Nebraska - Lincoln. 


\title{
FEEDING VALUE OF GRAIN SORGHUM FOR THE LACTATING SOW',2,3
}

\author{
G. F. Louis, A. J. Lewis ${ }^{4}$ and E. R. Peo, Jr. \\ University of Nebraska ${ }^{5}$, Lincoln 68583-0908
}

\begin{abstract}
Two experiments were conducted to investigate the effects of a corn-soybean meal (CSBM) and a sorghum-soybean meal (S-SBM) diet on reproductive performance and nutrient utilization by sows. In Exp. 1, 75 sows (39 gilts; 36 primiparous) were fed either a C-SBM or a S-SBM gestation diet from breeding to $\mathrm{d} 109$. On d 110, sows were assigned to lactation diets; half of the sows from each dietary treatment were assigned to a lactation diet based on the opposite grain. Sow weight change from d 54 to farrowing was greater $(P$ $<.06)$ for sows fed S-SBM than for sows fed C-SBM. There was no difference $(P>.50)$ in weight change of sows during lactation. Feed consumption during lactation was greater $(P$ $<.01$ ) for sows fed C-SBM than for sows fed S-SBM. Litter size at birth and d 21 did not differ between treatments $(P>.13)$. Litter weights at birth were similar, but litters of sows fed C-SBM gained more weight $(P<.05)$ during the $21-d$ lactation than those fed S-SBM. There were no differences $(P>.30)$ in the number of days from weaning to estrus. In Exp. 2 , the energy and $\mathrm{N}$ metabolism of the two diets was compared in 12 lactating, primiparous sows from d 15 to 20 of lactation. Dry matter digestibility, DE and ME percentages were not affected by grain source $(P>.46)$. Apparent $N$ digestibility, apparent biological value and $\mathrm{N}$ balance were higher for the C-SBM than for the S-SBM diet $(P<.05)$. Sows fed the C-SBM diet during lactation consumed more feed, utilized more of the dietary $\mathrm{N}$ and had litters with greater weight gains than sows fed the S-SBM diet.

Key Words: Sows, Maize, Sorghum, Reproductive Performance, Energy, Nitrogen
\end{abstract}

J. Anim. Sci. 1991. 69:223-229

Introduction

Grain sorghum is often included in diets of pigs; the low-tannin varieties are considered to have $95 \%$ of the feeding value of com for growing-finishing swine (Tanksley, 1974; Cousins et al., 1981; Holden et al., 1984). The reduced efficiency of feed utilization for

\footnotetext{
${ }^{1}$ Journal Series No. 9157, Agric. Res. Div., Univ. of Nebraska. Research reported was conducted under Project 13-081.

${ }^{2}$ Partial financial support was provided by the Nebraska Grain Sorghum Development, Utilization and Marketing Board.

${ }^{3}$ The technical assistance of R. M. Diedrichsen, M. A. Giesemann, J. L. Kovar and C. H. Naber is gratefully acknowledged.

${ }^{4}$ To whom reprint requests should be addressed.

${ }^{5}$ Dept. of Anim. Sci.

Received March 19, 1990.

Accepted July 18, 1990.
}

sorghum vs corn for growing-finishing pigs (Hodson et al., 1973; White et al., 1983) may be related to the lower ME content and lower N digestibility of some varieties of sorghum (Tanksley, 1974; Serra et al., 1982).

Sorghum-based diets fed to sows during gestation (Danielson, 1967; Luce et al., 1989) and lactation (Luce et al., 1989) support adequate reproductive performance. However, no direct comparisons have been drawn between com and sorghum as the grain in lactation diets. Furthermore, measurements of sorghum digestibility and utilization obtained from growing-finishing pigs may not prove applicable to lactating sows.

The present research consisted of two experiments. The objective of the first was to compare the reproductive performance of sows fed a sorghum-based diet with that of sows fed a corn-based diet. The objective of the second was to measure energy and $N$ utilization by lactating sows fed these two diets. 
TABLE 1. ANALYZED COMPOSITION OF THE GRAINS ${ }^{\mathrm{a}}$

\begin{tabular}{llc}
\hline Item & Corn & Sorghum $^{\mathrm{bc}}$ \\
\hline GE, Mcal/kg & 3.77 & 3.81 \\
CP, \% & 9.4 & 11.0 \\
Amino acids, \% & & \\
Arginine & .33 & .35 \\
Histidine & .24 & .23 \\
Isoleucine & .28 & .42 \\
Leucine & 1.01 & 1.44 \\
Lysine & .29 & .25 \\
Methionine + cystine & .48 & .45 \\
Phenylalanine + tyrosine & .76 & .94 \\
Threonine & .31 & .36 \\
Tryptophan & .06 & .09 \\
Valine & .42 & .59 \\
\hline
\end{tabular}

${ }^{a}$ Values are expressed on a $90 \%$ DM basis.

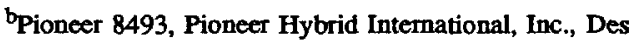
Moines, IA.

${ }^{\mathrm{c}}$ Tannin content $=.08 \%$ catechin equivalents.

\section{Experimental Procedure}

Experiment 1. In this experiment there were four factors in a $2 \times 2$ arrangement. The first two factors were the feeding period, either gestation or lactation, and the second two factors were the grains fed within each period, either yellow dent corn or low-tannin bronze sorghum (Table 1). Corn-soybean meal (C-
SBM) gestation and lactation diets were formulated to contain 12 and $14 \% \mathrm{CP}$, respectively. The corn was ground with a hammer mill fitted with a $6.35-\mathrm{mm}$ screen. Grain sorghum replaced com on an equal weight basis in the sorghum-soybean meal (SSBM) diets (Table 2). Sorghum was rolled so that the particle size of the S-SBM diet would be similar to that of the C-SBM diet (geometrical mean diameter was $1,191 \mu \mathrm{m}$ with a SD of 2.06 for S-SBM, and $957 \mu \mathrm{m}$ with a SD of 1.77 for C-SBM). Minerals and vitamins were added at levels to meet or exceed the NRC (1988) requirements. No antibiotics were included in the diets.

Seventy-five (39 gilts; 36 primiparous) crossbred (Landrace $\times$ Large White $\times$ Hampshire $\times$ Duroc) sows were allotted at random within parity to the two gestation diets at breeding. They were fed $2.0 \mathrm{~kg} / \mathrm{d}$ from breeding to $d 54$. The sows were then moved from outside lots to individual gestation crates in a room maintained at $20 \pm 1^{\circ} \mathrm{C}$ and fed 1.8 $\mathrm{kg} / \mathrm{d}$ for the remainder of gestation. On d 109 of gestation, the sows were moved to farrowing crates. The mean daily minimum and maximum temperature in the farrowing room was 19.5 and $21^{\circ} \mathrm{C}$, respectively, and a $50 \%$ relative humidity was maintained. A

TABLE 2. COMPOSITION OF DIETS

\begin{tabular}{|c|c|c|c|c|}
\hline \multirow[b]{2}{*}{ Item } & \multicolumn{2}{|c|}{ Gestation } & \multicolumn{2}{|c|}{ Lactation } \\
\hline & Corn & Sorghum & Corn & Sorghum \\
\hline \multicolumn{5}{|l|}{ Ingredient, \% } \\
\hline Ground com & 84.80 & & 69.05 & \\
\hline Rolled sorghum & & 84.80 & & 69.05 \\
\hline Soybean meal ( $44 \%$ CP) & 10.40 & 10.40 & 16.10 & 16.10 \\
\hline Beet pulp & & & 10.00 & 10.00 \\
\hline Dicalcium phosphate & 2.70 & 2.70 & 2.65 & 2.65 \\
\hline Ground limestone & .50 & .50 & .60 & .60 \\
\hline Iodized salt & .50 & .50 & .50 & .50 \\
\hline Vitamin premix ${ }^{a}$ & 1.00 & 1.00 & 1.00 & 1.00 \\
\hline Trace mineral mix ${ }^{b}$ & .05 & .05 & .05 & .05 \\
\hline Selenium premix ${ }^{\mathfrak{c}}$ & .05 & .05 & .05 & .05 \\
\hline \multicolumn{5}{|l|}{ Chemical analysis } \\
\hline GE, Mcal/kg diet & 3.78 & 3.69 & 3.73 & 3.75 \\
\hline $\mathrm{CP}, \%$ & 12.2 & 14.3 & 13.6 & 15.5 \\
\hline Lysine, \% & .60 & .56 & .76 & .75 \\
\hline $\mathrm{Ca}, \%$ & .83 & 1.12 & 1.10 & .89 \\
\hline $\mathbf{P}, \%$ & .81 & 1.08 & .92 & .86 \\
\hline
\end{tabular}

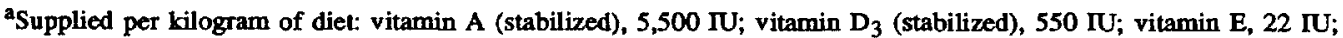
menadione sodium bisulfite, $2.2 \mathrm{mg}$; riboflavin, $5.5 \mathrm{mg}$; d-pantothenic acid, $19.8 \mathrm{mg}$; niacin, $33 \mathrm{mg}$; choline chloride, 550 $\mathrm{mg}$; vitamin $\mathrm{B}_{12}, 16.5 \mu \mathrm{g}$; ethoxyquin, $4.4 \mathrm{mg}$.

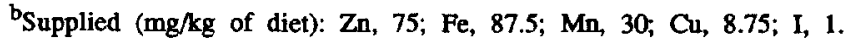

${ }^{\mathrm{c}}$ Supplied (mg/kg of diet): $\mathrm{Se}, .3$. 
1.2- $\mathrm{m}^{2}$ covered creep area with supplemental heat (temperature was $32^{\circ} \mathrm{C}$ ) was provided for each litter. Fluorescent lights supplied continuous lighting. On d 110 of gestation, sows were changed from their gestation diets to their lactation diets and fed $1.8 \mathrm{~kg} / \mathrm{d}$ until farrowing. Half the sows fed com during gestation were selected at random and switched to sorghum diets, and vice versa. Sows had ad libitum access to feed throughout lactation; both the sows and their pigs had access to nipple waterers.

Sows were weighed at breeding, on d 54 and 109 of gestation, within $24 \mathrm{~h}$ after parturition and on $\mathrm{d} 7,14$ and 21 of lactation. Feed intake was recorded for $\mathrm{d} 1,2,3,4$ to 7 , 8 to 14 and 15 to 21 of lactation. At parturition, the number of pigs born alive, pigs born dead and mummies were counted and birth weights were recorded. There was no crossfostering of pigs between litters. At $3 \mathrm{~d}$ of age, pigs were injected with $150 \mathrm{mg}$ of iron dextran and the male pigs were castrated. The number and weights of pigs on $d 7,14$ and 21 were recorded. Litters were not given supplemental feed, but they did have some access to their dams' feed.

On d 21, pigs were weaned and sows were moved to pens, where they were grouped within treatment. The sows were fed $1.8 \mathrm{~kg} / \mathrm{d}$ of the gestation diets containing the same grain as their lactation diet. Beginning $2 \mathrm{~d}$ postweaning, each sow was checked daily by a mature boar for estrus. Willingness to stand for the boar was defined as being in estrus. After $d 10$ postweaning, estrus detection was terminated.

Experiment 2. This experiment involved 12 lactating, primiparous, Landrace $\times$ Large White sows. The general procedures were the same as those described for Exp. 1. Of the six sows assigned to each of the lactation treatments, three had been assigned to a gestation diet based on the opposite grain source. Litters were equalized to 10 pigs by d 3 of lactation and maintained at 10 pigs throughout the experiment.

The lactation diets were the same as those in Exp. 1. The dietary treatments were initiated on d 110 of gestation. From d 110 to farrowing, the sows were fed $1.8 \mathrm{~kg} / \mathrm{d}$. After farrowing, sows had ad libitum access to their respective diets until d 10 of lactation. From d 11 to 23 sows were fed $4.5 \mathrm{~kg} / \mathrm{d}$ in two equal feedings. During this period, orts were collected, dried and refed before the next feeding.
Sows were housed in individual farrowing crates designed to allow collection of feces and orts from under the crates. Feces resulting from $\mathrm{d} 15$ to 20 lactation intakes were collected from the sows. The first feeding on the morning of the 15th and the 20th $d$ of lactation contained $.5 \%$ ferric oxide $\left(\mathrm{Fe}_{2} \mathrm{O}_{3}\right)$ as a visible marker to demarcate the beginning and end of the feces collection period. Feces were collected daily and frozen.

On d 14 of lactation, sows were fitted with indwelling bladder catheters (Foley catheter, size 20,5-ml balloon) to enable total collection of urine. Urine collection began on the morning of d 16 and continued until the moming of $\mathrm{d} 21$. Urine was collected in plastic vessels containing $100 \mathrm{ml}$ of $3.15 \% \mathrm{HCl}$. Urine volume was measured daily after diluting the total volume to the nearest $100 \mathrm{ml}$ with water. The urine was mixed thoroughly and a $2 \%$ aliquot was obtained, pooled by sow and frozen daily.

Chemical and Statistical Analyses. Feces were homogenized and DM was determined by oven-drying at $60^{\circ} \mathrm{C}$. Samples of the two grains, four diets and dried feces were ground through a $1-\mathrm{mm}$ screen before chemical analysis. Nitrogen and GE content of the grains (Table 1), diets (Table 2), and feces and urine samples were determined by the AOAC (1984) procedure and adiabatic bomb calorimetry, respectively. Grain amino acid (Table 1) and diet lysine (Table 2) content was determined after $20 \mathrm{~h}$ of acid hydrolysis $(6 \mathrm{~N} \mathrm{HCl})$, under $\mathrm{N}$, at $107^{\circ} \mathrm{C}$. Amino acids were separated by ion exchange HPLC. After elution from the chromatography column, the amino acids were measured fluorometrically using $o$-phthalaldehyde (1,2-benzene dicarbonal) as the derivatizing reagent. Tryptophan was measured by the fluorometric procedure described by Lewis et al. (1976), after alkaline hydrolysis. The tannin content of the grain sorghum was determined using the vanillin- $\mathrm{HCl}$ method (Burns, 1971).

In Exp. 1, data were analyzed statistically as a factorial arrangement of treatments with the sow as the experimental unit and parity included as a covariate. In Exp. 2, data were analyzed as a randomized complete block design with location within the room as the block and sow as the experimental unit. Gross energy intake and $N$ intake were included as covariates. The GLM procedure of SAS (1985) was used for all statistical analyses. 
TABLE 3. EFFECT OF LACTATION DIET ON SOW PERFORMANCE (EXP. 1)

\begin{tabular}{|c|c|c|c|c|}
\hline \multirow[b]{2}{*}{ Item } & \multicolumn{2}{|c|}{ Grain } & \multirow[b]{2}{*}{$\boldsymbol{P}$} & \multirow[b]{2}{*}{$\mathrm{CV}$} \\
\hline & Corn & Sorghum & & \\
\hline No. of sows & 38 & 37 & & \\
\hline \multicolumn{5}{|l|}{ Average daily feed intake, $\mathrm{kg}$} \\
\hline Day 1 & 4.77 & 4.01 & .08 & 29.7 \\
\hline Day 2 & 3.89 & 4.01 & .76 & 41.4 \\
\hline Day 3 & 4.34 & 3.55 & .01 & 40.7 \\
\hline Days 4 to 7 & 5.12 & 4.65 & .09 & 28.7 \\
\hline Days 8 to 14 & 6.42 & 5.64 & .01 & 23.9 \\
\hline Days 15 to 21 & 6.59 & 5.98 & .02 & 18.8 \\
\hline Days 1 to 21 & 5.93 & 5.31 & .01 & 17.2 \\
\hline \multicolumn{5}{|l|}{ Sow wt, kg } \\
\hline Postpartum wt change $\mathrm{e}^{\mathrm{a}}$ & -9.79 & -10.49 & .67 & 69.7 \\
\hline Lactation wt change ${ }^{\mathrm{b}}$ & -9.91 & -11.03 & .59 & 85.5 \\
\hline Weaning to estrus interval, $d$ & 5.1 & 5.4 & .30 & 26.5 \\
\hline
\end{tabular}

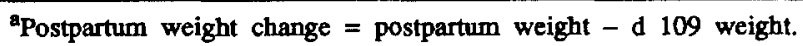

bactation weight change $=$ weaning weight - postpartum weight.

\section{Results}

Experiment 1. At the time of breeding, sow weights averaged 140.1 and $139.5 \mathrm{~kg}$ for the sows fed the C-SBM and S-SBM gestation diets, respectively. Weight gain from d 0 to 54 of gestation was not affected $(P>.60)$ by grain source (14.4 and $15.1 \mathrm{~kg}$ for the sows fed CSBM and S-SBM, respectively), but from d 54 to 109 of gestation, sows fed the S-SBM diet gained more weight $(P<.06)$ than sows fed the C-SBM diet $(19.7$ vs $16.9 \mathrm{~kg})$. This difference was not expected; although it was statistically significant, a difference of $<3 \mathrm{~kg}$ probably has little biological significance. There was no interaction $(P>.10)$ between the gestation and lactation grain source for any of the traits and there were no effects $(P>.13)$ of gestation diet on lactation performance. Therefore, for the lactation results, only the main effects of the lactation grain source are reported.

The effects of grain source on sow performance during lactation are summarized in Table 3. Sows fed the C-SBM diet consumed more feed than sows fed the S-SBM diet during each period $(P<.09$, except $\mathrm{d} 2)$ and over the 21-d lactation $(P<.01)$. There was no difference in postpartum weight change $(P>$ $.60)$, and, despite the $11.7 \%$ difference in lactation feed intake, there was no difference $(P>.50)$ in sow weight loss from farrowing to d 21 of lactation. Also, there was no difference $(P>.30)$ in the length of the interval from weaning to estrus between the sows fed the two treatments. All sows expressed estrus by d 10 postweaning.

Litter size at birth (live, dead and mummies) and at $\mathrm{d} 7,14$ and 21 did not differ $(P>$ .13) between the two treatments (Table 4), Although sows assigned to the S-SBM lactation diet tended to have more live pigs at birth than the sows assigned to the C-SBM lactation diet, this was not attributed to the grain source in either their gestation $(P>.61)$ or lactation diets $(P>.13)$. Litters of sows fed the C-SBM diet gained more weight $(P<.05)$ from $\mathrm{d} 0$ to 21 of lactation than those of sows consuming the S-SBM diet.

Experiment 2. The effects of lactation grain source on energy and $\mathrm{N}$ metabolism are summarized in Table 5. During the time that metabolism data were collected (d 15 to 20 of lactation) there were no differences between treatments $(P>.15)$ in either sow weight loss or litter weight gain. Although GE intake, DM digestibility, DE and ME were numerically greater for sows fed the C-SBM diet than for sows fed the S-SBM diet, none of these differences was significant $(P>.40)$. The ME values were $97 \%$ of the values for $D E$.

Apparent $\mathrm{N}$ digestibility of the C-SBM diet $(79.3 \%)$ was greater $(P<.02)$ than that of the S-SBM diet $(70.3 \%)$. Of the $N$ that was digested and absorbed, a higher $(P<.01)$ percentage of the $\mathbf{N}$ from the C-SBM diet was utilized than from the S-SBM diet. This resulted in apparent biological values (BV) of $69.9 \%$ and $62.7 \%$ for the C-SBM diet and SSBM diet, respectively. Both apparent $N$ digestibility and apparent BV were higher for 
TABLE 4. EFFECT OF LACTATION DIET ON LITTER PERFORMANCE (EXP. 1)

\begin{tabular}{|c|c|c|c|c|}
\hline \multirow[b]{2}{*}{ Item } & \multicolumn{2}{|c|}{ Grain } & \multirow[b]{2}{*}{$P$} & \multirow[b]{2}{*}{$\mathrm{CV}$} \\
\hline & Corn & Sorghum & & \\
\hline No. of litters & 38 & 37 & & \\
\hline Pigs farrowed live & 10.25 & 11.11 & .13 & 22.8 \\
\hline Pigs farrowed dead & .31 & .55 & .18 & 170.8 \\
\hline Mummies & .68 & .68 & .94 & 169.3 \\
\hline Pigs at $7 \mathrm{~d}$ & 9.48 & 9.64 & .76 & 24.1 \\
\hline Pigs at $14 \mathrm{~d}$ & 9.19 & 9.45 & .62 & 24.4 \\
\hline Pigs at $21 \mathrm{~d}$ & 9.11 & 9.40 & .58 & 24.4 \\
\hline Litter wt at birth, $\mathrm{kg}$ & 15.32 & 15.18 & .84 & 20.4 \\
\hline Litter wt at $21 \mathrm{~d}, \mathrm{~kg}$ & 55.48 & 51.63 & .08 & 17.7 \\
\hline Litter wt gain from d 0 to $21, \mathrm{~kg}^{\mathrm{a}}$ & 41.99 & 38.84 & .05 & 20.1 \\
\hline
\end{tabular}

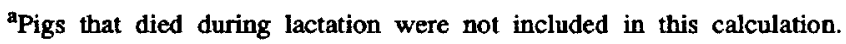

the C-SBM diet; thus, there was a large difference $(P<.05)$ in $\mathrm{N}$ balance, the sows fed the C-SBM diet retaining $10.7 \mathrm{~g} / \mathrm{d}$ more $\mathrm{N}$ than the sows fed the S-SBM diet. These N balance data do not include $\mathrm{N}$ excreted in milk, but litter size was equalized to 10 pigs to standardize milk $\mathrm{N}$ output as much as possible.

\section{Discussion}

Sows fed the C-SBM diet consumed more energy and protein during the 21-d lactation than sows consuming the S-SBM diet. This probably contributed to the greater weight gains of the litters from sows fed the C-SBM diet than gains of those from sows consuming the S-SBM diet. Previously, Brendemuhl et al. (1987) reported that the protein intake of sows can affect pig weight gain; pig weight gains are also influenced by dietary energy intake of multiparous sows (Reese et al., 1982a,b). In primiparous sows, pig growth and survival are generally not affected by energy restriction when protein intake is maintained constant during lactation (King and Williams, 1984; Reese et al., 1984). Primiparous sows may be able to mobilize more energy reserves than multiparous sows to maintain milk yield (O'Grady et al., 1973). In the present research, a separate statistical analysis in which parity was included as a main effect instead of a covariate revealed that, regardless of whether the sows were primiparous or multiparous, litter weight gains were lower $(P<.05)$ when sows were fed S-SBM than when they were fed C-SBM (parity $\times$ diet interaction, $P>.70$ ).

Neither the DM digestibility nor energy utilization differed significantly due to the

TABLE 5. EFFECT OF LACTATION DIET ON ENERGY AND NITROGEN METABOLISM (EXP. 2) ${ }^{\text {a }}$

\begin{tabular}{lcccc}
\hline \hline & \multicolumn{2}{c}{ Grain } & & \\
\cline { 2 - 4 } Item & Corn & Sorghum & $P$ & CV \\
\hline No. of sows & 6 & 6 & & 5.2 \\
GE intake, Mcal/d & 16.85 & 16.43 & .43 & 3.0 \\
Apparent DM digestibility, \% & 84.17 & 83.04 & .48 & 3.2 \\
DE, \% & 84.10 & 83.05 & .53 & 3.1 \\
ME, \% & 81.85 & 80.65 & .46 & 5.4 \\
N intake, g/d & 94.93 & 99.17 & .20 & 6.2 \\
Apparent N digestibility, \% & 79.27 & 70.33 & .02 & .01 \\
Apparent BV, \% & 69.94 & 62.66 & .01 & 8.4 \\
N balance, g/d & 53.51 & 42.85 & .05 & \\
\hline
\end{tabular}

${ }^{a}$ Mean weight on d 109 of gestation was 153 and $151 \mathrm{~kg}$ for sows fed the corn-soybean meal diet and the sorghumsoybean meal diet, respectively. Litter size was standardized to 10 pigs/sow. During the period when metabolism data were collected (d 15 to 20) sow weight changes were $-.55 \mathrm{~kg} / \mathrm{d}$ for C-SBM and $-.77 \mathrm{~kg} / \mathrm{d}$ for $S-S B M(P>.30)$, and litter weight gains were $1.70 \mathrm{~kg} / \mathrm{d}$ for C-SBM and $1.95 \mathrm{~kg} / \mathrm{d}$ for S-SBM $(P>.15)$. 
dietary grain source. This finding is in agreement with the results of metabolism studies using growing swine that have compared low-tannin varieties of grain sorghum to yellow corn. Diggs et al. (1965) and Cousins et al. (1981) reported that diets based on these two grain sources had essentially the same DM digestibility, GE, DE and ME when fed to growing swine.

Although there was no difference in energy utilization, sows consuming the C-SBM diet utilized a greater proportion of their dietary $\mathrm{N}$ than sows consuming the S-SBM diet. This finding is also consistent with previous research. Tribble et al. (1972) demonstrated in finishing pigs that the $\mathrm{N}$ digestibility of cornbased diets was greater than that of sorghumbased diets ( 80 vs $73 \%$ ). Although the trends were not statistically significant $(P>.10)$, Cousins et al. (1981), in a trial with 50-kg pigs fitted with T-cannulas at the terminal ileum, found that the digestibility of $\mathrm{N}$ and of most amino acids was higher from com than from sorghum.

The greater $\mathrm{N}$ utilization of the C-SBM diet may be related to the protein structure of the grains. Rooney and Pflugfelder (1986) reported that although the protein composition of com and sorghum endosperm is similar, important differences exist. Sorghum kafirins (prolamines) are crosslinked. The crosslinks decrease the digestibility of the enmeshed protein.

The reduced utilization of $\mathbf{N}$ (lower $\mathrm{BV}$ ) of the S-SBM diet is more difficult to explain. Possibly, a limiting amino acid in the S-SBM diet reduced utilization of $\mathrm{N}$. In experiments with lactating sows in which dietary lysine levels were $\leq .53 \%$ (Lewis and Speer, 1973) or threonine levels were $\leq .42 \%$ (Lewis and Speer, 1975), $N$ retention and reproductive performance were decreased. Thus, the reduced $\mathrm{N}$ retention of sows and lower weight gain of litters from sows consuming the S-SBM diet may have been caused by an amino acid deficiency. Although the calculated lysine and threonine levels were $.76 \%$ and $.53 \%$, respectively, for the C-SBM and .75\% and $.56 \%$, respectively, for the S-SBM diet, potential differences in amino acid availabilities must be considered. Stephenson et al. (1971) reported that the availability of lysine and threonine for chicks differed among sorghum cultivars (58.3 to $92.5 \%$ for lysine and 46.8 to $91.8 \%$ for threonine).

\section{Implications}

Both corn- and sorghum-based diets, when fed to sows during gestation and lactation, can support a high level of reproductive performance (more than nine pigs/litter weaned). However, sows fed a com-soybean meal diet during lactation consumed more feed and utilized a greater proportion of their dietary $\mathrm{N}$ than those fed a sorghum-soybean meal diet. Litters of sows fed the corn-soybean meal diet gained more weight than litters of sows fed the sorghum-soybean meal diet during a 21-d lactation. Thus, these results indicate that com and sorghum were of equal value in gestation diets, but that corn was superior to sorghum as the basis of a diet for lactating sows.

\section{Llterature Clted}

AOAC. 1984. Official Methods of Analysis (14th Ed). Association of Official Analytical Chemists, Washington, DC.

Brendemuhl, J. H., A. J. Lewis and E. R. Peo, Jr. 1987. Effect of protein and energy intake by primiparous sows during lactation on sow and litter performance and sow serum thyroxine and urea concentrations. J. Anim Sci. 64:1060.

Burns, R. E. 1971. Method for estimation of tannin in grain sorghum. Agron. J. 63:511.

Cousins, B. W., T. D. Tanksley, Jr., D. A. Knabe and T. Zebrowska. 1981. Nutrient digestibility and performance of pigs fed sorghums varying in tannin concentration. J. Anim. Sci. 53:1524.

Danielson, M. 1967. Swine diet studies - wheat, sorghum, corn compared. Univ. of Nebraska Coll. of Agric. and Home Econ. Quarterly 11(2):18.

Diggs, B. G., D. E. Becker, A. H. Jensen and H. W. Norton. 1965. Energy value of various feeds for the young pig. J. Anim. Sci. 24:555.

Hodson, H. H., R. Snyder and G. H. Kroening. 1973. Com vs. milo for the pig with varying levels of protein and lysine. J. Anim. Sci. 37:283 (Abstr.).

Holden, P., L. Frobish and J. Pettigrew. 1984. Energy for Swine. Pork Industry Handbook PIH-3. Purdue Univ., West Lafayette, IN.

King, R. H. and I. H. Williams. 1984. The effect of nutrition on the reproductive performance of first-litter sows. 1. Feeding level during lactation, and between weaning and mating. Anim. Prod. 38:241.

Lewis, A. J., P. J. Holden, R. C. Ewan and D. R. Zimmerman. 1976. An automated fluorometric method for the measurement of tryptophan in plasma. J. Agric. Food Chem. 24:1081.

Lewis, A. J. and V. C. Speer. 1973. Lysine requirement of the lactating sow. J. Anim. Sci. 37:104.

Lewis, A. J. and V. C. Speer. 1975. Threonine requirement of the lactating sow. J. Anim. Sci. 40:892.

Luce, W. G., C. V. Maxwell, D. S. Buchanan, A. C. Clutter and M.D. Woltmann. 1989. Comparisons of wheat and sorghum grain for gestating gilts. J. Anim. Sci. 67(Suppl. 1):247 (Abstr.). 
NRC. 1988. Nutrient Requirements of Swine (9th Ed.). National Academy Press, Washington, DC.

O'Grady, J. F., F.W.H. Elsley, R. M. MacPherson and I. McDonald. 1973. The response of lactating sows and their litters to different dietary energy allowances. 1. Milk yield and composition, reproductive performance of sows and growth rate of litters. Anim. Prod. 17:65.

Reese, D. E., B. D. Moser, E. R. Peo, Jr., A. J. Lewis, D. R. Zimmerman, J. E. Kinder and W. W. Stroup. 1982a. Influence of energy intake during lactation on the interval from weaning for first estrus in sows. J. Anim. Sci. 55:590.

Reese, D. E., B. D. Moser, E. R. Peo, Jr., A. J. Lewis, D. R. Zimmerman, J. E. Kinder and W. W. Stroup. 1982b. Influence of energy intake during lactation on subsequent gestation, lactation and postweaning performance of sows. J. Anim. Sci. 55:867.

Reese, D. E., E. R. Peo, Jr. and A. J. Lewis. 1984. Relationship of lactation energy intake and occurrence of postweaning estrus to body and backfat composition in sows. J. Anim. Sci. 58:1236.

Rooney, L. W. and R. L. Pflugfelder. 1986. Factors affecting starch digestibility with special emphasis on sorghum and corn. J. Anim. Sci. 63:1607.

SAS. 1985. SAS User's Guide: Statistics. SAS Inst., Inc., Cary, NC.

Serra, P.M.A.A., O.E.R. Oliveira and T. H. Fernandes. 1982. A note on the use of sorghum as a substitute for maize in a diet for growing pigs. Anim. Prod. 35:443. Stephenson, E. L., J. O. York, D. B. Bragg and C. A. Ivy. 1971. The amino acid content and availability of different strains of grain sorghum to the chick. Poult. Sci. 50:581.

Tanksley, T. D., Jr. 1974. Progress reports of swine nutrition research at Texas A\&M. I. Comparison of yellow corn and three sorghum grains with different endosperm types for growing-finishing swine. p 57. Proc. Swine Short Course, Texas A\&M Univ., College Station.

Tribble, L. F., A. M. Lennon, C. T. Gaskins Jr., K. L. Clapp and C. B. Ramsey. 1972. Various grains in swine rations at same lysine level. J. Anim. Sci. 35:226 (Abstr.).

White, C. E., J. R. Rich, D. R. Campbell and M. E. Swisher. 1983. Performance of swine fed com or grain sorghum grown in identical field environment. p 48. Florida Annu. Swine Field Day, Gainesville. 